\title{
Isolation and Characterization of Antithrombin Peptides from the Saliva of Malaysian Leeches
}

\author{
Mohamed Alaama ${ }^{1^{*}}$, ABM Helal Uddin ${ }^{1^{*}}$, Abbas Mohammad Ghawi ${ }^{2}$, Ahmed \\ Merzouk $^{3}$, Abdualrahman Mohammed Abdualkader ${ }^{1}$, and Mohamed bin Awang ${ }^{4}$ \\ ${ }^{1}$ Department of Pharmaceutical Chemistry, ${ }^{2}$ Department of Basic Medical Science, Faculty of Pharmacy, International Islamic \\ University Malaysia (IIUM), 25200 Kuantan, Malaysia, ${ }^{3}$ Biopep Solutions Inc, Vancouver, BC, Canada, ${ }^{4}$ Faculty of Pharmacy, \\ CUCMS, Cyberjaya, Selangor.
}

*For correspondence: Email: hass83pharm@yahoo.com, abmhelal@iium.edu.my

\begin{abstract}
Purpose: To isolate and characterize the antithrombin compounds of Malaysian leeches' saliva collection (LSC) for use as anticoagulant proteins and peptides.

Method: Reversed phase - high performance liquid chromatography (RP-HPLC) was used to isolate all proteins from LSC. All isolated proteins were tested for anticoagulant activity by applying two tests, thrombin time test and the inhibition of the amidolytic activity of thrombin on the chromogenic substrate (S-2238). The molecular weights of isolated active compounds were identified using tricine sodium dodecyl sulfate-polyacrylamide gel electrophoresis (SDS- PAGE).

Results: More than 40 proteins were isolated from LSC using RP-HPLC. Two compounds (protein 1 and protein 2) were found to be active as they increased thrombin time by 30.26 and $36.75 \%$, respectively and inhibited the amidolytic activity of thrombin. as evaluated by measuring the conversion of the chromogenic substrate (S-2238). Decrease in the conversion of the substrate (S-2238) by 31.10 and $41.61 \%$, respectively was observed. The molecular weights of the proteins (6.289 and $14.255 \mathrm{kDa}$, respectively) had no similarity with other leech species.

Conclusion: Two antithrombin proteins with anticoagulant properties were isolated from the saliva of Malaysian leeches using one-step isolation procedure. The proteins did not show any similarity to previous isolated proteins from leech.
\end{abstract}

Keywords: Leech, Saliva, Antithrombin, Anticoagulant, Peptides, Molecular weight

Tropical Journal of Pharmaceutical Research is indexed by Science Citation Index (SciSearch), Scopus, International Pharmaceutical Abstract, Chemical Abstracts, Embase, Index Copernicus, EBSCO, African Index Medicus, JournalSeek, Journal Citation Reports/Science Edition, Directory of Open Access Journals (DOAJ), African Journal Online, Bioline International, Open-J-Gate and Pharmacy Abstracts

\section{INTRODUCTION}

Leeching and leech saliva extracts have received much attention because of their extensive use in many traditional and conventional medical fields [1]. Nowadays, leeches are used for several medical ailments like: arthritis, blood clotting disorders, eye diseases, post-operative venous congestion, and even in modern plastic reconstructive surgery [2]
Leech's saliva contains many active compounds which have several biological activities, as anticoagulants, vasodilatants, anesthetics, thrombolytics, antibiotics, analgesics, antimetastasis and anti-inflammatory agents [3]. The anticoagulant compounds help to keep the host blood in the liquid state during sucking $[2,4,5]$ as well as its storage in leech's digestive system, making its digestion easier $[1,6]$

These anticoagulants are mainly proteins and peptides secreted by the leech's salivary glands 
[1]. The anticoagulant activity of Hirudo medicinalis leeches was first described by Haycraft [7]. This anticoagulant compound was found to be a protein in nature and it was named hirudin [8]. Later, hirudin was isolated in the pure state and was fully characterized $[4,9]$. On the other hand, the saliva constituents of other species of leeches have been studied and a number of proteins and peptides have been found $[5,10]$

Hirudinaria manillensis is another species of leeches belonging to the same family of Hirudo medicinalis and it is widely found in south-east Asia including Malaysia. Several active compounds have been isolated from its saliva like bufridin from the head of Hirudinaria leech [11], hirullin P6 and P18 from the whole body of the leech [12], and Hirudin variant HM2 was expressed in Escherichia coli utilizing a synthetic gene [13].

In Malaysia, the use of leeches is still under traditional medicine and there are a few studies about Malaysian leeches in terms of isolation and characterization of anticoagulant compounds. The aim of this study is to isolate and characterize anticoagulant proteins especially antithrombin peptides and proteins from the saliva of Malaysian leeches.

\section{EXPERIMENTAL}

\section{Leeches}

Hirudinaria manillensis (Lesson 1842) Leeches were collected from Cheneh Lake, Terengganu, Malaysia. They were kept in the laboratory at room temperature under 12-12 hours light dark cycle in plastic containers with perforated cover to allow air circulation. The water in the container was changed every three days.

\section{Chemicals and Reagents}

The following chemicals and reagents were used in this study: L-Arginine Hydrochloride; Tris base; Sodium Dodecyl Sulfate (SDS) electrophoresis grade; Acrylamide electrophoresis grade; Trifluoroacetic acid (TFA) HPLC grade and UltraLow Molecular Weight Peptide Marker 1.02 - 26 $\mathrm{kD}$ were purchased from Sigma Aldrich (USA). Sodium Chloride; Bis-acrylamide electrophoresis grade; Coomassie Blue electrophoresis grade and Tricin electrophoresis grade; were supplied by Merck (Germany). Acetonitrile HPLC grade; Glacial Acetic Acid; Glycerol; Bromophenol Blue electrophoresis grade and Glycine electrophoresis grade; were supplied from Fisher (UK).
Chromogenic substrate S2238 was obtained from Idna (Singapore). Thromboclotine was purchased from Siemens (Germany). Tetramethylethylenediamine (TEMED) electrophoresis grade; Ammonium Per Sulfate (APS) electrophoresis grade and 2 - Mercaptoethanol electrophoresis grade; were obtained from Bio Rad (USA). Glycerol electrophoresis grade was purchased from Ajax Finechem (Australia).

\section{Collection of leeches' saliva extract}

Saliva of leeches was collected following the method described by Alaama et al [14]. The extract was collected in glass tubes, lyophilized and kept at $-20^{\circ} \mathrm{C}$.

\section{Isolation of proteins using RP-HPLC}

Lyophilized saliva extract was dissolved in HPLC water to an estimated concentration of $1000 \mu \mathrm{g}$ $/ \mathrm{ml}$ from which $100 \mu \mathrm{l}$ was taken and injected through an automatic injector connected to an Agilent reversed phase C18 column $(4.5 \times 150$ $\mathrm{mm} \times 5 \mu \mathrm{m})$. Buffer A (0.1\% TFA in water) and buffer $B(0.1 \%$ TFA in acetonitrile) were used as mobile phases. A linear gradient of $5-90 \%$ buffer B over 40 min was used for the elution. The absorbance detection was fixed at $214 \mathrm{~nm}$. Every peak was collected and isolated as a separate compound. All compounds were collected, frozen at $-40^{\circ} \mathrm{C}$, and then lyophilized. Every compound was dissolved in $60 \mu \mathrm{l}$ of distilled water and used to check for the activity thrombin time and amidolytic activity.

\section{Thrombin time}

Citrated plasma was obtained by mixing fresh human blood with sodium citrate (9 parts of blood +1 part of $0.11 \mathrm{~mol} / \mathrm{l}$ sodium citrate) and subsequently centrifuging at $1600 \mathrm{rpm}$ at room temperature for $10 \mathrm{~min}$. A volume of $80 \mu \mathrm{l}$ of citrated plasma were added to $20 \mu \mathrm{l}$ of isolated compounds solution and the feeding solution (control) and incubated at $37^{\circ} \mathrm{C}$ for $2 \mathrm{~min}$. Then $100 \mu \mathrm{l}$ of thrombin reagent at $37^{\circ} \mathrm{C}$ was added using a pipette, and the time until coagulation started was measured in a photometric coagulometer (sysmix Ca50) in triplicate.

Control plasma test was always run before the experiment to evaluate the precision and accuracy of the reagents used and the coagulometer. Each vial of Control $\mathrm{N} \circledast$ was dissolved in $1.0 \mathrm{ml}$ distilled water, shaken gently and let to stand for $15 \mathrm{~min}$ at room temperature. 
The reconstituted control plasma was kept at -20 ${ }^{\circ} \mathrm{C}$ for a maximum period of four weeks according to Control $N \circledast$ manual. The present increase in thrombin time (\% TT) was calculated from the equation:

$\mathrm{TT}(\%)=\{(\mathrm{TT} s-\mathrm{TT}$ cp $) / \mathrm{TT} c \mathrm{p})\}$

where TTs and TTcp are the thrombin time of the sample and citrated plasma, respectively.

Every protein which prolonged thrombin time was determined as active antithrombin protein [15].

\section{Amidolytic activity inhibition assay}

A volume of $250 \mu \mathrm{l}$ of thrombin $(0.124 \mathrm{IU} / \mathrm{ml}$, final concentration $0.1 \mathrm{IU} / \mathrm{ml}$ ) in Tris buffer (Tris 50 $\mathrm{mmol} / \mathrm{l}, \mathrm{NaCl} 154 \mathrm{mmol} / \mathrm{l}, \mathrm{pH}$ 8.0) was introduced into a micro-plate reader (micro-titer plates). This solution was mixed with $10 \mu$ l solvent (control) or isolated compounds solution for $1 \mathrm{~min}$ and incubated at $25^{\circ} \mathrm{C}$ for $4 \mathrm{~min}$. The reaction was then started by adding $50 \mu$ l of substrate solution (S-2238 (H-D -phenylalanyl-L-pipecolyl-Larginine-p-nitroanilide dihydrochloride), 0.62 $\mathrm{mmol} / \mathrm{l})$ to a final concentration of $(0.1 \mathrm{mmol} / \mathrm{l})$, briefly mixing and then incubation at $25^{\circ} \mathrm{C}$. After $5 \mathrm{~min}$, the reaction was stopped by adding $50 \mu \mathrm{l}$ of $35 \%$ acetic acid, and the absorbance at 405 $\mathrm{nm}$ was measured. All proteins which reduced the absorbance at $405 \mathrm{~nm}$ were considered as active antithrombin proteins [15].
Determination of molecular weight of active proteins

Tricine SDS-PAGE was run to determine the molecular weight of active proteins as described [18], using 16\% gel. Samples were prepared by mixing the same amount of sample and sample buffer and heating the mixture for $5 \mathrm{~min}$ at $95^{\circ} \mathrm{C}$, and then they were applied to the gel using micropipette. All gels were stained using Coomassie Blue.

\section{Statistical analysis}

All data were derived from at least three independent experiments. Statistical Analysis of the data were carried out using one way analysis of variance (ANOVA) and the Tukey post hoc test for average comparison on SPSS 18.0. Mean values \pm S.D. were used. Significance was defined as $p<0.05$.

\section{RESULTS}

\section{Proteins isolation}

Leeches' saliva proteins were isolated by RPHPLC as shown in Figure 1. A total of 40 peaks were isolated from the Hirudinaria manillensis leeches' saliva. Each peak was frozen at $-40^{\circ} \mathrm{C}$ and lyophilized, then used for testing, after dissolving in $60 \mu \mathrm{l}$ distilled water to assess the anticoagulant activity.



Figure 1: Chromatogram of isolated proteins from the saliva of leeches (as indicated by arrows). $\mathrm{P} 1$ : protein 1; P2 protein 2 
The results using a Sysmix CA 50 coagulometer revealed the presence of two active proteins that are able to extend the thrombin time. They prolonged the thrombin time by $30.26 \%$ and $36.75 \%$ respectively as reported in Table 1 . They were designated as protein 1 and protein 2 . The other 38 fractions did not affect the thrombin time so they were not considered for other tests.

The two isolated proteins were assessed for their inhibition of amidolytic activity of thrombin. The results revealed that protein 1 and protein 2 inhibited the amidolytic activity of thrombin by $31.10 \%$ and $41.61 \%$ respectively as shown in Table 1. These results supported the earlier results obtained with thrombin time.

Table 1: Antithrombin activity of isolated proteins from leeches' saliva collection (LSC).

\begin{tabular}{|c|c|c|c|}
\hline \multirow[t]{2}{*}{ Sample } & \multicolumn{2}{|c|}{ TT test } & \multirow{2}{*}{$\begin{array}{l}\text { Inhibition of } \\
\text { amidolytic } \\
\text { activity (\%) }\end{array}$} \\
\hline & $T T(s)$ & $\begin{array}{c}T T \text { inhibition } \\
(\%)\end{array}$ & \\
\hline $\begin{array}{l}\text { Control } \\
\text { plasma }\end{array}$ & $20.5 \pm 0.1$ & - & - \\
\hline $\begin{array}{l}\text { Citrated } \\
\text { plasma }\end{array}$ & $19.5 \pm 0.1$ & 0 & - \\
\hline Protein 1 & $25.4 \pm 0.1$ & $30.26 \pm 0.42^{\alpha}$ & $31.1 \pm 2.2$ \\
\hline Protein 2 & $26.7 \pm 0.2$ & $36.75 \pm 0.87^{\alpha, \beta}$ & $41.6 \pm 5.1$ \\
\hline
\end{tabular}

The molecular weights for two active isolated proteins were also determined using the Tricine SDS- PAGE. The results in Figure 2 revealed that the molecular weights of the two active proteins were: $6289.799 \mathrm{Da}$ and $14244.58 \mathrm{Da}$ respectively.

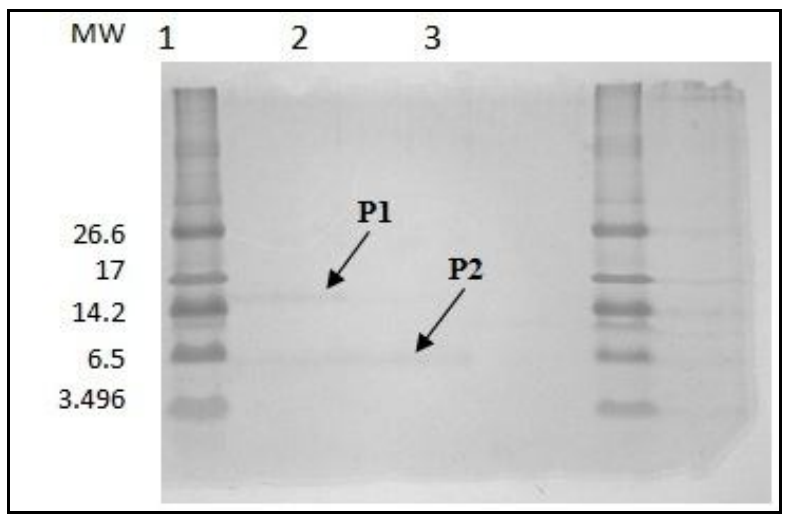

Figure 2: Molecular weight of active isolated proteins using Tricin SDS-PAGE. Lane 1: peptide marker, P1: protein 1 the first active peak. P2: protein 2 the second active peak.

A comparison between the molecular weight of these two proteins with the library of active compounds isolated from other leech species was conducted and reported in Table 2.

The comparison showed no similarity between the isolated proteins from Malaysian leeches' saliva collections and other proteins and peptides isolated from other leech species.

Table 2: Comparison of isolated antithrombin proteins from this study with other antithrombin proteins isolated from various leech species

\begin{tabular}{llcc}
\hline Compound & $\begin{array}{l}\text { Leech } \\
\text { specie }\end{array}$ & $\begin{array}{c}\text { Molecular } \\
\text { weight }\end{array}$ & Reference \\
\hline Protein 1 & $\begin{array}{l}\text { Hirudinaria } \\
\text { manillensis }\end{array}$ & 6289.799 & This study \\
\hline Hirullin P18 & $\begin{array}{l}\text { Hirudinaria } \\
\text { manillensis }\end{array}$ & $6600-6800$ & {$[12]$} \\
\hline Bufridin & $\begin{array}{l}\text { Hirudinaria } \\
\text { manillensis }\end{array}$ & 7000 & {$[13]$} \\
\hline Haemadin & $\begin{array}{l}\text { Haemadipsa } \\
\text { sylvestris }\end{array}$ & 5300 & {$[16]$} \\
\hline Hirudin & $\begin{array}{l}\text { Hirudo } \\
\text { medicinalis }\end{array}$ & 7000 & {$[17]$} \\
\hline Protein 2 & $\begin{array}{l}\text { Hirudinaria } \\
\text { manillensis }\end{array}$ & 14244.58 & This study \\
\hline Theromin & $\begin{array}{l}\text { Theromyzon } \\
\text { tessulatun }\end{array}$ & 14500 & {$[5]$} \\
\hline
\end{tabular}

\section{DISCUSSION}

Hirudinaria manillensis is known as buffalo leech because it depends on the mammals' blood for feeding. It is believed that Hirudinaria might develop more suitable tools for feeding in mammals' blood as it was stated in some studies that these leeches have specialized jaws to bite mammals' skin [19]. It is believed also that these species of leeches have developed suitable anticoagulant compounds for mammals' blood. Malaysian leeches are classified under Hirudinaria manillensis species and they have been applied traditionally for medical treatments for ages. In this study the isolated anticoagulant proteins are believed to be new due to their high effect on thrombin, and their molecular weights which are not similar to any known isolated anticoagulant compound. The use of RP-HPLC for the isolation of proteins was described before [5] for the isolation of antimicrobial proteins from medicinal leeches. RP-HPLC is an easy and accurate method for isolation of protein and one step isolation helps in reducing the risk of yield and activity loss.

\section{CONCLUSION}

In conclusion, we have isolated two antithrombin proteins from the saliva of Malaysian leech. They are believed to be new compounds as they showed no similarity with other isolated proteins from other leeches. 


\section{ACKNOWLEDGEMENT}

This research was supported by a grant (EDW B 10-0393) from Research-Management Centre, International Islamic University Malaysia.

\section{REFERENCES}

1. Sawyer RT. Leech Biology and Behavior: Volume II: Feeding Biology, Ecology, and Systematics. USA: Oxford University Press; 1986; $p 360$.

2. Govedich FR; \& Bain BA. All About Leeches Intruduction. 2005 [cited 2010 June 12]. Available from: http://www.invertebrate.us/leech/.

3. Kraemer BA, Korber KE, Aquino TI, Engleman A. Use of leeches in plastic and reconstructive surgery: a review. J Reconstr Microsurg 1988;4(5): 381-386.

4. Markwardt F. Die Isolierung und chemische Charakterisierung des Hirudins. Hoppe-Seyler's Zeitschrift für physiologische Chemie 1957; 308 (Jahresband): 147-156.

5. Salzet M, Chopin V, Baert J, Matias I, Malecha J. Theromin, a novel leech thrombin inhibitor. J Biol Chem 2000; 275(40): 30774-30780.

6. Mann $\mathrm{KH}$, Leeches (Hirudinea) their structure, physiology, ecology and embryology. New York: Pergamon Press; 1962; p 201.

7. Haycraft JB. The action of a secretion obtained from the medicinal leech on a coagulation of blood. Proc. $R$. Soc. London 1884; 36: 478-487.

8. Bodong A. Über Hirudin. Arch Exp Pathol Pharmakol 1905; 52: 242-261.

9. Bagdy D, Barabas É, Gráf L, Petersen T E, Magnusson S. [54] Hirudin. In: L. Laszlo, Editor. Methods in Enzymology. London: Academic Press INC 1976. pp 669-678.
10. Nutt E, Gasic T, Rodkey J, Gasic GJ, Jacobs J W, Friedman PA, Simpson E. The amino acid sequence of antistasin. A potent inhibitor of factor $X a$ reveals a repeated internal structure. J Biol Chem 1988; 263(21): 10162-10167.

11. Electricwala $A$, Sawyer $R T$, Jones $C P$, Atkinson $T$. Isolation of thrombin inhibitor from the leech Hirudinaria manillensis. Blood Coagul Fibrinolysis 1991; 2(1): 83-89.

12. Steiner $S$, Knecht $R$, Gruetter $R$. Isolation and purification of novel hirudins from the leech Hirudinaria manillensis by high-performance liquid chromatography. J Chromatogr. 1991; 530: 273-282.

13. Scacheri E, Nitti G, Valsasina B, Orsini G, Visco $C$, Ferreia M, Sawyer RT. Sarmientos $P$. Novel hirudin variants from the leech Hirudinaria manillensis: Amino acid sequence, cDNA cloning and genomic organization. Eur. J. Biochem 1993; 214: 295-304

14. Alaama M, Najjar M, AbdualKade AM, Mohammad A, Merzouk A. Isolation and Analytical Characterization of Local Malaysian Leech Saliva. IIUM Engineering J 2011; 12(4): 51-59

15. Abdualkader MA, Merzouk A, Ghawi AM, Alaama M. Some Biologica Activities of Malaysian Leech Saliva Extract. IIUM Engineering J 2011; 12(4): 1-9.

16. Strube $K H$, Kröger B, Bialojan S, Otte $M$, Dodt J. Isolation, sequence analysis, and cloning of haemadin. An anticoagulant peptide from the Indian leech. J Biol Chem 1993; 268(12): 8590-8595.

17. Dodt J, Schmitz T, Schäfer T, Bergmann C. Expression, secretion and processing of hirudin in E. coli using the alkaline phosphatase signal sequence. FEBS Letters 1986; 202(2): 373-377.

18. Schägger $H$, Von Jagow G. Tricine-sodium dodecyl sulfate-polyacrylamide gel electrophoresis for the separation of proteins in the range from 1 to $100 \mathrm{kDa}$. Anal Biochem. 1987; 166(2): 368-379.

19. Electricwala A., Hartwell R., Scawen M, Atkinson T. The complete amino acid sequence of a hirudin variant from the leech Hirudinaria manillensis. J Protein Chem 1993; 12(3): 365-370. 